\title{
DOES TQM SUPPORT INNOVATION PERFORMANCE IN MALAYSIA'S MANUFACTURING INDUSTRY?
}

\author{
Keng-Boon Ooi ${ }^{1}$, Binshan Lin ${ }^{2}$, Pei-Lee Teh ${ }^{3}$, Alain Yee-Loong Chong ${ }^{4}$ \\ ${ }^{1}$ Faculty of Business and Finance, University Tunku Abdul Rahman, 31900 Kampar, \\ Perak Darul Ridzuan, Malaysia \\ ${ }^{2}$ Business School, Louisiana State University in Shreveport, Shreveport, LA 71115, USA \\ ${ }^{3}$ Faculty of Management, Multimedia University, Persiaran Multimedia, 63100 Cyberjaya, \\ Selangor Darul Ehsan, Malaysia \\ ${ }^{4}$ Department of Industrial and Systems Engineering, Hong Kong Polytechnic University, \\ Kowloon, Hung Hom, Hong Kong, China \\ E-mails: ${ }^{1}$ ooikengboon@gmail.com; ${ }^{2}$ binshan.lin@lsus.edu; \\ 3peilee_t@yahoo.com; ${ }^{4}$ alain.chong@gmail.com (corresponding author)
}

Received 17 March 2011; accepted 30 May 2011

\begin{abstract}
This empirical study examines the association of TQM practices (i.e. leadership, customer focus, strategic planning, people management, information analysis and process management) with the innovation performance as perceived by the managers in Malaysia. The research model is constructed on the basis of established theory and on well-known criteria such as Malcolm Baldrige National Quality Award. Six hypotheses are formulated and tested by multiple regression based on a sample of 206 managers working in the ISO 9001:2000 certified manufacturing firms in Malaysia. The results of this study show that TQM has a significant positive relationship with innovation performance. In particular, the findings of this study show that process management, strategic planning, people management and customer focus have positive relationships with innovation performance of firms surveyed in Malaysia. Therefore, both researchers and practitioners are advised to consider these relevant TQM practices when assessing the innovation performance of an organization. Implications for managers and researchers, as well as study limitations are also discussed.
\end{abstract}

Keywords: TQM, innovation, Malaysia, manufacturing industry, multiple regression analysis, MBNQA, ISO 9000 quality system series.

Reference to this paper should be made as follows: Ooi, K. B.; Lin, B.; Teh, P. L.; Chong, A. Y. L. 2012. Does TQM support innovation performance in Malaysia's manufacturing industry?, Journal of Business Economics and Management 13(2): 366-393.

JEL Classification: L15, O32, N65, C30, M11.

\section{Introduction}

Total quality management (TQM) has been widely used by many organizations and it has been applied as a management philosophy to provide customer and quality focused practices (Singh, Smith 2004; Easton, Jarrell 1998; Zafiropoulos, Vrana 2008). TQM 
has been recognized to play an important role for achieving competitive advantage for organizations (Prajogo, Sohal 2004a, 2004b). Given the importance of TQM, there are not many companies, especially those in manufacturing sectors can afford to ignore TQM (Prajogo, Sohal 2003; Dean, Bowen 1994). As Prajogo and Sohal (2006), and Bolwijn and Kumpe (1990) stated, in today's competitive environment, organizations are required to pursue more complex dimensions of performance, especially in both innovation and quality.

Innovation plays a significant role in helping business to attain a sustainable competitive edge (Prajogo, Sohal 2003; Tushman, Nadler 1986), especially in developing countries such as Malaysia where industrial growth has become an integral part of the economic development. In a hypercompetitive global environment, business organizations in the developing countries are increasingly seeking for innovation, shifting away from the previous focus on cost reduction for long term success (Shah Alam, Yasin 2010). Given that the manufacturing industry is the key driver for social and economic development in the developing countries (Zeng et al. 2010), promoting innovation should be one of the priorities of the developing countries in their economic agenda.

The link between TQM and innovation has stirred up a huge interest among scholars in the management field (Feng et al. 2006) and there are different arguments relating to the association between TQM and innovation (Prajogo, Sohal 2001). Although studies have been conducted by previous scholars to investigate the relationship between TQM and innovation performance around the globe, especially in the Western countries (Prajogo, Sohal 2003; Singh, Smith 2004; Tidd et al. 1997; Wind, Mahajan 1997; Slater, Narver 1998; McAdam et al. 1998), there are very few studies on the influence of TQM dimensions on innovation performance in the developing countries such as Malaysia, particularly within the context of the manufacturing sector.

A review of the recent literature showed that some researchers have explored the issues of innovation performance in developing countries such as the relationship between technology transfer and innovation performance (Guan et al. 2006), cooperation networks and innovation performance (Zeng et al. 2010), manufacturing strategies and innovation performance (Prajogo et al. 2007), and the determinants of innovation performance (Wang, Kafouros 2009). However, the aforementioned publications have limited their empirical studies within the context of China, Taiwan, Thailand and Vietnam. In accordance to the Malaysian Industrial Development Authority (2009), a report published by the Economist Intelligence Unit (2009) has shown that Malaysia was ranked No. 31 among the 82 countries on a survey - "A New Ranking of the World's Most Innovative Countries". In the same survey published by the Economist Intelligence Unit (2009), China was ranked No. 54, India was positioned No. 56, Thailand was ranked No. 58, Indonesia was ranked No. 74, and by such measures, Malaysia has surpassed these developing countries in Asia in terms of innovation performance. In this regard, Malaysia provides an interesting and appropriate context for examining the relationship between TQM practices and innovation performance.

This study is motivated by the need to examine the influence of TQM practices on innovation performance in the manufacturing industry in Malaysia. Although Malaysia was 
initially an agro-based economy, Malaysia has now become one of the fastest growing developing countries, having achieved significant rates of growth in the manufacturing sector over the past decades. Today, the manufacturing industry still makes up a major sector of Malaysia's economy, contributing approximately 40 percent of gross domestic product (GDP). Following the latest report from the Economist Intelligence Unit (2010), the manufacturing output raised by $12.9 \%$ year on year, and the values of merchandise exports and imports, production by the manufacturing and electricity industries and the rate of manufacturing sales increased by double digit rates in December 2009.

From the aspect of sociocultural impact on innovations in industry, Malaysia has an advantage of population profile, principally workforce's age and education levels. According to the Department of Statistics Malaysia (2010), Malaysia has a population of 28.31 million in 2009, in which 63.6 percent of the population is between 15-64 years old, 31.8 percent is below 15 years old, and 4.6 percent is above 65 years old. The proportion of people between 15-64 years old consists of 62.6 percent out of the total labor force in Malaysia, that is, 11.466.700 (Labor Force Survey 2010). Many of these working people aged between 15-64 years old are Generation Y employees. These Generation $\mathrm{Y}$ employees are educated, mostly up to levels roughly equivalent to United States high school diploma level, and they grew up technologically aware, globally conscious and internet savvy. Unlike many of the older employees, these young people are more likely to be outward looking, willing to challenge the status quo and be concerned about the innovation performance in the organization. Moreover, Malaysia has been experiencing the influx of skilled foreign workers in more than a decade, because Malaysia's standard of living is higher than surroundings countries (e.g., India, Indonesia, Philippines, Thailand, Cambodia and Laos). The number of foreign workers in the manufacturing industry in Malaysia is reported at 728.867 in year 2008 (Ministry of Home Affairs 2010). This is partly because of the wide usage of English, which makes working and living easy for the more educated foreign workers who are proficient in English.

In this regard, the study on the linkage between TQM and innovation performance is important as it provides a theoretical as well as a practical platform for the Malaysian manufacturing industries to gain sustainable competitive advantage. In order to provide organizations with a better perspective on the relationship between TQM and innovation performance, this paper aims to examine whether the application of TQM practices allows organizations, in particular, the ISO 9001:2000 certified manufacturing organizations within the Malaysian manufacturing industry, to build their competence and competitiveness through innovation. This study differs from existing studies because it focuses on the application of TQM practices in a developing economy, that is, Malaysia.

\section{Literature review and formulation hypothesis}

\subsection{TQM practices}

The global interest in implementing TQM implies that the principles and techniques of TQM are universal and practical across firms, industries and countries. For instance, the institutionalization of regional quality award (e.g., Minnesota Quality Award), national quality award (e.g., Australian National Quality Award) and international quality 
award (e.g., European Foundation Quality Management Award) are events reflecting that TQM is universally applicable and valuable (Rungtusanatham et al. 1998). Theoretically, TQM is a management philosophy that can be described by its principles (i.e. customer focus, continuous improvement, and teamwork), practices, and techniques (Kanji 1998; Dean, Bowen 1994; Schonberger 1992).

The Malcolm Baldrige National Quality Award (MBNQA) framework has served as the basis model of TQM for many researchers (Jung, Wang 2006; Choi, Eboch 1998). The Malcolm Baldrige National Quality Improvement Act of 1987 set up an annual USA MBNQA which comprises criteria associated with TQM (Miranda 2003). These six criteria are leadership, strategic planning, customer focus, information analysis, people management, and process management (Prajogo, Hong 2008; Miranda 2003; Prajogo, Sohal 2003). These six elements of MBNQA have been accepted to represent TQM practices by many scholars such as Evans and Lindsay (1999), Dean and Bowen (1994). According to Samson and Terziovski (1999), numerous manufacturing firms in the United States, Europe, Australia as well as Japan have also adopted and implemented these six dimensions in their companies. Furthermore, these six elements of MBNQA could be used to review the quality improvement of any type or size of organizations (Hart, Schlesinger 1991).

Based on an extensive review of the past studies (e.g., Prajogo, Hong 2008; Prajogo, Sohal, 2003; Wilson, Collier 2000; Samson, Terziovski 1999; Choi, Eboch 1998), six constructs of TQM practices namely leadership, strategic planning, customer focus, information analysis, people management, and process management have been chosen to be analyzed in this study (see Table 1).

\subsection{Innovation performance}

Innovation is defined as "the development and implementation of new ideas by people who over time engage in transactions with others within an institutional order" (Van de Ven 1986: 590). Innovation has long been known as one of the most significant sources of competitive advantage (Prajogo, Sohal 2006; Narver, Slater 1990). Apart from that, it has been acknowledged as an essential ingredient for firms' long term success and survival (Ehigie, McAndrew 2005; Oldham, Cummings 1996; Scott, Bruce 1994). Earlier research have identified a wide range of benefits such as higher profits and market share, for business companies which have gained knowledge from the use of innovation strategies (Prajogo, Ahmed 2006; Narver, Slater 1990; Cooper 1993; Calantone et al. 1995; Griffin 1997; Han et al. 1998). According to Montes et al. (2003), innovating novel products and services can help to improve people's lives, create a new market segment for the company, and new improvements in the production methods and tools. Pinho (2008) and Damanpour (1996) hypothesize that innovation involves undertaking activities to improve the products, processes or procedures, which can help to enhance the value and performance of products, processes or procedures. As proposed by Prajogo and Sohal (2001) and Cooper (1998), academics and practitioners have spent a lot of time searching and identifying organizational factors, practices and materials that can help to support and improve innovation. From a practical point of view, an organization which implements an integrated set of TQM practices could facilitate innovation performance. 
Table 1. List of studies and dimensions of TQM

\begin{tabular}{|c|c|c|}
\hline $\begin{array}{l}\text { TQM practices and } \\
\text { performance measures }\end{array}$ & $\begin{array}{l}\text { Description of TQM practices } \\
\text { and performance measures }\end{array}$ & $\begin{array}{l}\text { Supporting literature for TQM and } \\
\text { performance measures }\end{array}$ \\
\hline Leadership & $\begin{array}{l}\text { Top management and supervisory } \\
\text { commitment and leadership; } \\
\text { public responsibility and } \\
\text { citizenship }\end{array}$ & $\begin{array}{l}\text { Flynn et al. (1994), Powell } \\
\text { (1995), Wilson and Collier (2000), } \\
\text { Prajogo and Sohal (2001), } \\
\text { Sun and Cheng (2002) }\end{array}$ \\
\hline Strategic Planning & $\begin{array}{l}\text { Quality mission, goals and } \\
\text { policy; strategy development } \\
\text { and deployment }\end{array}$ & $\begin{array}{l}\text { Prajogo and Sohal (2001), } \\
\text { Raghunathan et al. (1997), } \\
\text { Solis et al. (2000), } \\
\text { Sun and Cheng (2002) }\end{array}$ \\
\hline Customer Focus & $\begin{array}{l}\text { Customer and market knowledge; } \\
\text { attention to innovation } \\
\text { performance; management } \\
\text { of customer relationship }\end{array}$ & $\begin{array}{l}\text { Powell (1995), Ahire et al. (1996), } \\
\text { Adam et al. (1997), Solis et al. } \\
\text { (2000), Sun and Cheng (2002), } \\
\text { Prajogo and Sohal (2003) }\end{array}$ \\
\hline Information Analysis & $\begin{array}{l}\text { Performance measurement } \\
\text { and analysis; information } \\
\text { management; use of information } \\
\text { technology; quality tools; } \\
\text { benchmarking }\end{array}$ & $\begin{array}{l}\text { Powell (1995), Samson and } \\
\text { Terziovski (1999), Prajogo and } \\
\text { Sohal (2001), Wilson and Collier } \\
\text { (2000), Solis et al. (2000), } \\
\text { Sun and Cheng (2002) }\end{array}$ \\
\hline People Management & $\begin{array}{l}\text { Employee involvement; } \\
\text { employee empowerment; } \\
\text { teamwork; rewards, recognition } \\
\text { and performance appraisal; } \\
\text { employee training }\end{array}$ & $\begin{array}{l}\text { Flynn et al. (1994), } \\
\text { Samson and Terziovski (1999), } \\
\text { Wilson and Collier (2000), } \\
\text { Sun and Cheng (2002) }\end{array}$ \\
\hline Process Management & $\begin{array}{l}\text { Product and service design; } \\
\text { process control; innovation } \\
\text { and continuous improvement } \\
\text { of processes, products } \\
\text { and services }\end{array}$ & $\begin{array}{l}\text { Saraph et al. (1989), Flynn et al. } \\
\text { (1994), Powell (1995), } \\
\text { Anderson et al. (1995), } \\
\text { Samson and Terziovski (1999), } \\
\text { Wilson and Collier (2000), } \\
\text { Sun and Cheng (2002) }\end{array}$ \\
\hline
\end{tabular}

Source: Adapted from Sila (2007)

Kirner et al. (2009) stated that innovation can be classified into two types, namely, product innovation and process innovation. Within the context of manufacturing firms, product innovation covers either physical or intangible products, and process innovation includes technological or organizational aspects (Kirner et al. 2009). Innovation performance is thus measured using three process innovation indicators: the production lead time, the employee productivity, and the rework or scrap rate (Kirner et al. 2009). The measures of product innovation performance include the share of sales of products or services launched in the last three years (Kirner et al. 2009). On the other hand, Mankin (2007) also suggested that the innovation performance can be assessed using four measures: (1) Amount of ideas funded; (2) Return on investment or project net present value; (3) Innovators in higher positions/CEO devotion; and (4) Long-term customer adoption. Since innovation is relatively complex, Mankin (2007) emphasized 
that each measure by itself is not able to capture the overall progress of innovation performance in an organization. Instead, the present study measures innovation performance through different aspects covering the results-based measure, process measures and project measures.

\subsection{TQM practices and innovation performance relationship}

\subsubsection{Leadership}

Leadership is the behaviour linked with the action of leading (Kanji 2008) and it is the force that "sow the seeds", in which leaders act as mediators who promote and communicate the new ideology (Savolainen 2000). Top management leadership is viewed as the primary element of quality performance (Ravichandran, Rai 2000), especially top management attitudes and behaviour are related to quality management practices in a firm (Flynn et al. 1994). In general, it is argued that leadership in an organization is vital for the culture of innovation, in which all employees should be empowered to make decisions, execute programs and use their creative ability (Rahman 2002).

Leadership style has been highlighted as one of the most significant influences on firm's innovation performance because the leaders can choose to launch new ideas directly into a technological organization, set precise goals, and promote innovation initiatives among its subordinates (Garcia-Morales et al. 2008; Kanter 1983; Senge et al. 1994). Another significant leadership role that is linked to innovation is to cultivate a 'fertile' ground that can foster innovation (Prajogo, Ahmed 2006; Martensen 1998; Jassawalla, Sashittal 2002). According to Ahmed (1998), it is the duty of leaders to present a culture and an environment that are able to cultivate and acknowledge innovation at every level. Therefore, firms should launch more "innovation champion(s)" that will help the company develop initiatives and build up leaders in innovation projects (Prajogo et al. 2007). Based on this discussion, a link is formed between leadership and innovation performance. The following hypothesis is proposed:

H1: Leadership is significantly and positively associated with innovation performance.

\subsubsection{Strategic planning}

Strategic planning is generally viewed as a management function which involves the resources allocation of planned activities that have been calculated to accomplish business goals (Gray 1986; Lisinski, Saruckij 2006). Strategic planning is used to guide the organization to stay focus on the chosen objectives (Choi, Eboch 1998).

Studies conducted by Carayannis et al. (2000) and Grant (1996) have indicated that a firm's competitiveness comes from the employees' specialised knowledge, the ability of the firm to create new knowledge and to innovate, and the strategic actions enabled by innovation. Martin and Horne (1993) and Maidique and Zirger (1984) stated that a well designed and co-ordinated process are more likely to guarantee a greater success for the new product. As innovative strategies and plans are being formulated, communicating these to all employees involved is seen to be important and crucial (Martensen, Dahlgaard 1999). A complete business strategy should incorporate a systematic plan for 
new products, connect the new product to the corporate goals, determine which market and technology to select as well as what transmission criteria to apply (Martensen, Dahlgaard 1999; Cooper 1993). However, Cottam et al. (2001) found that several organizations were confused about how to "fit" innovation into their organizations' overall business strategy and into their day-to-day working life. Drew (2006) and Mintzberg (1994) also highlighted that strategic planning is often criticized for having low levels of creativity and innovation. Therefore, Liedtka (2000) and Lorange (1980) argued that strategic planning should be aimed towards achieving a sufficient process of innovation that enables changes in the organization. Based on the above discussion, the following hypothesis is presented:

H2: Strategic planning is significantly and positively associated with innovation performance.

\subsubsection{Customer focus}

The overall planning and execution of quality programme must include the component of customer focus (Fuentes-Fuentes et al. 2004; Puffer, McCarthy 1996). One aspect of customer focus is to maintain a close relationship with the customers (Flynn et al. 1994). In order to identify customer needs and expectations, an organization must develop products and services that meet or exceed these expectations (Westphal et al. 1997; Flynn et al. 1994). The character of customer focus in motivating innovation has been discussed extensively in past literature (Abrunhosa, Sa 2008). This generates the impetus for companies to be innovative in order to meet customer needs through developing and initiating new products or services (Hoang et al. 2006). Specifically, from a company's perceptive, innovation provides an opportunity to improve its relationship with customers in the sense that it could drive the customers' current needs before being ordered by the customers in developing new products (Prajogo, Sohal 2004a, 2004b).

Being innovative helps to create a value among customers and thus improve performance of the firm with the objective to achieve a sustainable competitive advantage over its competitors (Mele, Colurcio 2006). In line with this, Jong and Hartog (2007) and Cooper (2003) stated that at a firm's level, innovation research has shown that customers' feedback can help to increase the success rate of new products in the market. As discussed above, customer focus is imperative for innovation performance, thus the following hypothesis is presented.

H3: Customer focus is significantly and positively associated with innovation performance.

\subsubsection{Information analysis}

Taylor and Wright (2003) stated that many researchers agreed that data and information should be at the heart of any TQM program. Data and analysis are used to make decisions in order to improve quality and productivity (Choi, Eboch 1998). Garvin (1983) posited that quality improvements are unlikely to take place without specific and timely information on defects and field failures. Information is important for firms to improve and enhance their innovation process, especially for firms that operate in 
the technology-based arena and which struggle to survive in the current competitive marketplace (Lemos, Porto 1998).

Geffen and Rothenberg (2000) and Cohen and Levinthal (1990) argued that it is important for firms to be able to identify new external information, absorb it and apply it in determining innovation capabilities. Furthermore, Krogh et al. (2001) also stated that existing customer information, customer group, data about original technologies, new manufacturing procedures etc. shall be integrated by the organizations in order to create incremental innovations. However, the activities to increase the understanding levels of the economic impact of innovation performance have been held back by the lack of continual widespread information on various factors contributing to innovation (Loof, Heshmati 2002). As a result, information must be the blood that enables innovative firms to survive (Lemos, Porto 1998). Therefore, the following hypothesis is developed:

H4: Information analysis is significantly and positively associated with innovation performance.

\subsubsection{People management}

People are considered as the most vital asset in today's knowledge-based economy (Fang 2005; Karnitis 2006) as people resource is one element that competitors cannot imitate (Rahman 2002). Employee's involvement is a vital part of any TQM effort, and the MBNQA has emphasized the importance of human resources (Bowen, Lawler III 1992) in their model. By using the term "people", rather than human resource, the present study includes more practices to those beyond the human resource function such as upward and downward communication, reward systems, work design and culture (Wright et al. 2001).

Employees from all levels of the organization should be encouraged to be involved in the innovation process of the company. This will enhance the innovation in the organizations, given that innovation mainly originates from people's efforts to interact with each other (Garcia-Morales et al. 2008; Hartman et al. 1994). In order to be innovative, every organization should maintain an environment that supports and encourages innovation. By doing so, the employees in the organization are not only 'willing' (i.e. motivated) to innovate, but 'can' (i.e. have opportunities) innovate as well (Prajogo, Ahmed 2006; Kanter 1983; Woodman et al. 1993; Claver et al. 1998). Based on the literature findings above, the following hypothesis has been formed.

H5: People management is significantly and positively associated with innovation performance.

\subsubsection{Process management}

Process management is a system of interrelated processes focusing on three initiatives: (1) mapping processes; (2) enhancing processes; and (3) adhering to documented organizational processes (Benner, Tushman 2003). For example, a good process management requires correctly defining and documenting process management procedures, with clear instructions for machine operation and setup placed at all workstation, in order to reduce the chances of operator error (Flynn et al. 1994). 
As organizations achieve higher levels of process management, the measures of effectiveness are accentuated in the aspect of efficiency, speed and costs or waste reduction, which involve process management extending to innovation development (Benner, Tushman 2003). These dynamics, especially in the manufacturing industry, can have a substantial impact on an organization's innovation performance. In this regard, a hypothesis supporting a positive relationship between process management and innovation is proposed.

H6: Process management is significantly and positively associated with innovation performance.

\section{Research methodology}

This section discusses the sample and data collection procedures, and operational measures of variables used in the study as well as the statistical tests used to evaluate the multidimensionality of TQM practices and its relationship with innovation performance.

\subsection{Sampling procedures}

In this study, the target population is the managers from the manufacturing organizations that are certified with the ISO 9000 quality system series. These firms are taken from the list of Federation of Malaysian Manufacturers (FMM) Directory (2007). Representing over 2000 manufacturing and industrial service companies of various sizes, FMM is a trade organization in Malaysia (FMM Directory 2007). As FMM is a well-known and prominent representative of the manufacturing and service industries for over 38 years, the selected sample in this study is considered to be a valid representation of the population. The respondents of this study are managers who possessed sufficient knowledge of their organizational practices pertaining to quality management, and have great knowledge about the levels of innovation performance in their organizations.

The empirical data was collected using a questionnaire survey. A random sample of 620 managers was selected from the ISO 9001 certified Malaysian manufacturing organizations indexed in FMM directory. Only one questionnaire per organization was included in the sample. Of the 620 questionnaires originally distributed, 206 were returned with usable answers. This constitutes an overall response rate of $33 \%$. The positions of the respondents in the organization are as follow: $63 \%$ of the respondents are production managers, operations managers and quality managers, $21 \%$ of them are senior managers such as general managers and managing directors and the remaining respondents are managers from other areas, such as human resource, finance, marketing and administration.

\subsection{Research instrument}

\subsubsection{Independent variables: TQM practices}

The independent variables in this study are based on the six dimensions of TQM adopted by Prajogo and Sohal (2003). The six dimensions are namely, leadership, customer focus, strategic planning, information analysis, process management and people management. Thus, a total of 37 statements are developed. In this study, sample questions 
include "Top management actively participates in quality management and improvement process" (leadership), "Our organization has a comprehensive and structured planning process which regularly sets and reviews short and long-term goals" (strategic planning), "Our organization always conducts market research in order to collect suggestions for improving our products" (customer focus), "Our organization has the ability to monitor all production/services processes to improve quality" (process management), "Our organization has a company-wide training and development process for all our employees" (people management) and "Our organization has undertaken benchmarking of other firms' product quality and procedures" (Information analysis). The statements are measured by a 5-point Likert scale ranging from $1=$ strongly disagree to $5=$ strongly agree.

\subsubsection{Dependent variable: innovation performance}

The measures of innovation performance were derived and adapted from several studies (Prajogo, Sohal 2003; Hoang et al. 2006; Singh, Smith 2004). Nine statements are developed under this construct. Respondents (i.e. managers) are asked to indicate their opinions about the innovation performance level in their organizations based on the five-point Likert scale $(1=$ strongly disagree; $2=$ disagree; $3=$ neutral; 4 = agree; $5=$ strongly agree). Some of the examples of the statements that measured innovation performance are as follows: "The updated-ness or novelty of technology used in process" (process innovation) and "The use of latest technological innovations in new product development" (product innovation).

\subsection{Statistical analysis}

Factor analysis was performed for the study variables. Reliability coefficients and intercorrelations were computed to determine the variability and interdependence of the subscales derived from the factor analyses (Ooi et al. 2006, 2008). Multiple regression analysis was then employed to examine the relationship between TQM practices and innovation performance.

\section{Results of the survey}

\subsection{Goodness of measures}

To ensure the reliability of data for both TQM practices and innovation performance, factor analysis and scale reliability analysis were used. Table 2 and 3 show the results of the factor analysis and reliability analysis. All individual loadings are above the minimum of 0.5 recommended by Hair et al. (1998). To examine the internal consistency of the measurement model, composite reliability is utilized. This is because it is similar to that of Cronbach's alpha "except that it also takes into account the actual factor loadings rather than assuming that each item is equally weighted in the composite load determination" (Lin, Lee 2004: 116). In addition, Chau and Hu (2001: 709) further confirm that by using the formula: "(Square of the summation of the factor loadings) / \{(Square of the summation of the factor loadings + (summation of error variances) $\}$ ", we can calculate the construct reliability. According to Molina et al. (2007), the minimum proposed value for reliability is 0.70 . As shown in Table 2, based on the above reasoning, 
the scales are all within the acceptable limits. Furthermore, the composite reliabilities of all latent constructs have also exceeded the benchmark of 0.7 as suggested by Nunnally and Bernstein (1994). This implies that the measurement is good thus the model being applied in this study is valid within reasonable statistical conditions.

Table 2. Factor analysis of TQM practices

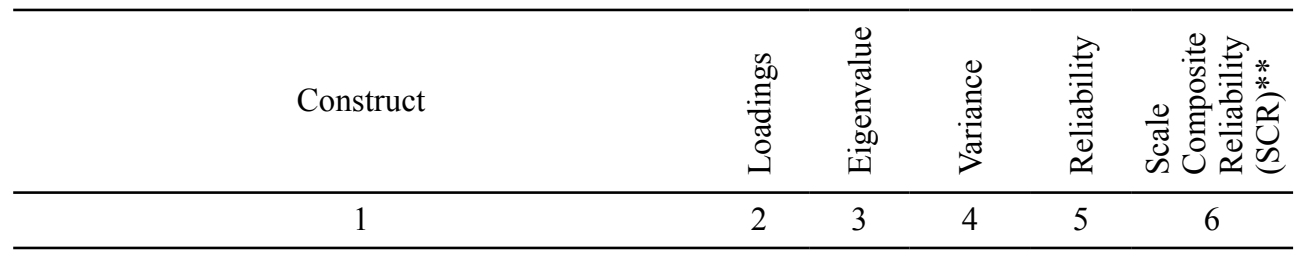

\section{Leadership (LD)}

\begin{tabular}{llllll}
\hline Top management actively participates in quality & 0.815 & 2.496 & 49.918 & 0.832 & 0.832
\end{tabular}
management and improvement process (LD1)

Top management strongly encourages employee $\quad 0.735$ involvement in quality management and improvement activities (LD3)

Top management learns quality-related concepts $\quad 0.669$ and skills (LD2)

Top management discusses many quality-related $\quad 0.657$ issues in top management meetings (LD6)

Top management pursues long-term business $\quad 0.647$ success (LD7)

\section{Strategic Planning (SP)}

Our organization has a comprehensive and $\begin{array}{lllll}0.744 & 2.394 & 47.889 & 0.821 & 0.823\end{array}$ structured planning process which regularly sets and reviews short and long-term goals (SP2)

Inclusion of continuous quality improvements $\quad 0.736$ in planning process (SP6)

Our organization always incorporates supplier $\quad 0.675$ capabilities, and needs of other stakeholders including the community when we develop our plans, policies and objectives (SP3)

Our organization has a mission statement which 0.663 has been communicated throughout the company and is supported by our employees (SP1)

Believe that strategic plans (and tactical plans) $\quad 0.648$ are linked to quality values (SP5)

\section{Customer Focus (CF)}

\begin{tabular}{lllllll}
\hline Quality-related customer complaints are treated & 0.787 & 3.306 & 55.101 & 0.884 & 0.880
\end{tabular} with top priority (CF2)

Our organization conducts a customer satisfaction 0.763 survey every year (CF3) 
Continue of Table 2

\begin{tabular}{|c|c|c|c|c|c|}
\hline 1 & 2 & 3 & 4 & 5 & 6 \\
\hline $\begin{array}{l}\text { Our organization has been customer focused for a } \\
\text { long time (CF6) }\end{array}$ & 0.747 & & & & \\
\hline $\begin{array}{l}\text { Our organization always conducts market research } \\
\text { in order to collect suggestions for improving our } \\
\text { products (CF4) }\end{array}$ & 0.746 & & & & \\
\hline $\begin{array}{l}\text { Our organization has precise knowledge of } \\
\text { customer expectations (CF7) }\end{array}$ & 0.724 & & & & \\
\hline $\begin{array}{l}\text { Our organization collects extensive complaint } \\
\text { information from customers (CF1) }\end{array}$ & 0.683 & & & & \\
\hline \multicolumn{6}{|l|}{ People Management (HR) } \\
\hline $\begin{array}{l}\text { Employee satisfaction is formally and regularly } \\
\text { measured (HR3) }\end{array}$ & 0.831 & 4.080 & 58.281 & 0.905 & 0.907 \\
\hline $\begin{array}{l}\text { Reward and recognition system within the } \\
\text { company rewards relationship and task } \\
\text { accomplishments based on work quality (HR7) }\end{array}$ & 0.821 & & & & \\
\hline
\end{tabular}

Our organization has a company-wide training and development process for all our employees (HR1)

\begin{tabular}{ll}
\hline $\begin{array}{l}\text { Employee flexibility, multi-skilling and training } \\
\text { are actively used to support performance }\end{array}$ & 0.770 \\
improvement (HR4) & \\
\hline $\begin{array}{l}\text { Our organization has maintained both "top-down” } \\
\text { and "bottom-up" communication processes (HR2) }\end{array}$ & \\
\hline $\begin{array}{l}\text { Our organization's compensations system } \\
\text { encourages team and individual contributions }\end{array}$ & 0.730 \\
(HR6) & \\
\hline $\begin{array}{l}\text { Our organization maintains a work environment } \\
\text { that contributes to the health, safety and well- }\end{array}$ & 0.631 \\
being of all employees (HR5) & \\
\hline
\end{tabular}

\section{Process Management (PM)}

\begin{tabular}{llllll}
\hline Our organization had at least one product/service & 0.763 & 3.613 & 51.610 & 0.888 & 0.882
\end{tabular} improvement in the past 1 year (PM6)

\begin{tabular}{ll}
\hline $\begin{array}{l}\text { Employees are encouraged to develop new and } \\
\text { innovative ways for better performance (PM2) }\end{array}$ & 0.750 \\
\hline $\begin{array}{l}\text { Use of statistical process control to monitor } \\
\text { production/service processes (PM8) }\end{array}$ & 0.713 \\
\hline Employees understand respective role (PM3) & 0.709 \\
\hline $\begin{array}{l}\text { Employees work as team but guided by clear } \\
\text { goals (PM1) }\end{array}$ & 0.707 \\
\hline $\begin{array}{l}\text { Our organization has the ability to monitor all } \\
\text { production/services processes to improve quality } \\
\text { (PM7) }\end{array}$ & 0.697 \\
\hline $\begin{array}{l}\text { Our organization has knowledge of lost customers } \\
\text { and investigates reason (PM4) }\end{array}$ & 0.687 \\
\hline
\end{tabular}


End of Table 2

\begin{tabular}{lccccc}
\hline \multicolumn{1}{c}{1} & 2 & 3 & 4 & 5 & 6 \\
\hline \multicolumn{1}{c}{ Information Analysis (IA) } & & & & & \\
\hline $\begin{array}{l}\text { Regular reviews on organization's quality } \\
\text { performance (IA1) }\end{array}$ & 0.801 & 3.873 & 55.332 & 0.895 & 0.896 \\
\hline $\begin{array}{l}\text { Availability of key performance figures for } \\
\text { analysis and decision making (IA4) }\end{array}$ & 0.788 & & & & \\
\hline
\end{tabular}

Our organization analyzes all work processes and 0.767 systems (IA3)

Our organization has undertaken benchmarking of 0.738 other firms' product quality and procedures (IA7)

Availability of regular strategic planning (IA5) 0.708

Knowledge, availability, access and collection of 0.700 data (IA2)

Our organization has undertaken benchmarking $\quad 0.698$ relative to cost position (IA6)

Note: Items SP4, SP7, LD4, LD5, PM5 and CF5 were deleted due to low factor loadings.

$\left.* * \operatorname{SCR}=(\Sigma \lambda i)^{2} /\left[(\Sigma \lambda i)^{2}+\Sigma \delta i\right)\right],(\lambda i=$ standardized factor loadings, $i=$ observed variables, $\delta i=$ error variance)

Table 3. Factor analysis of innovation performance

\begin{tabular}{|c|c|c|c|c|c|}
\hline Innovation Performance & 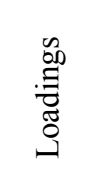 & 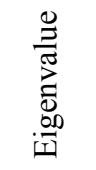 & 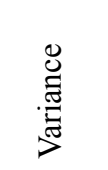 & 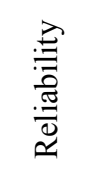 & 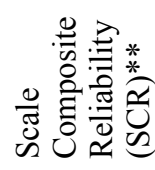 \\
\hline $\begin{array}{l}\text { The level of newness (novelty) of new products } \\
\text { (IP8) }\end{array}$ & 0.845 & 4.975 & 55.822 & 0.916 & 0.917 \\
\hline $\begin{array}{l}\text { The use of latest technological innovations in new } \\
\text { product development (IP6) }\end{array}$ & 0.811 & & & & \\
\hline The speed of new product development (IP7) & 0.773 & & & & \\
\hline $\begin{array}{l}\text { The number of new products introduced to the } \\
\text { market (IP3) }\end{array}$ & 0.745 & & & & \\
\hline $\begin{array}{l}\text { The number of new products that is first-to-market } \\
\text { (early market entrants) (IP5) }\end{array}$ & 0.743 & & & & \\
\hline The technological competitiveness (IP9) & 0.727 & & & & \\
\hline $\begin{array}{l}\text { The updated-ness or novelty of technology used in } \\
\text { process (IP1) }\end{array}$ & 0.703 & & & & \\
\hline $\begin{array}{l}\text { The speed of adoption of the latest technological } \\
\text { innovations in process (IP4) }\end{array}$ & 0.680 & & & & \\
\hline $\begin{array}{l}\text { The rate of change in processes, techniques and } \\
\text { technology (IP2) }\end{array}$ & 0.643 & & & & \\
\hline
\end{tabular}

Note: $\left.* * \operatorname{SCR}=(\Sigma \lambda i)^{2} /\left[(\Sigma \lambda i)^{2}+\Sigma \delta i\right)\right],(\lambda i=$ standardized factor loadings, $i=$ observed variables, $\delta i=$ error variance) 


\subsection{Correlation analysis: relationships between independent variables}

The correlation matrix in Table 4 indicates correlation coefficients between the independent variables in this research. The correlation coefficient indicates the strength of the link between the variables. A correlation is considered significant if the $p$-value is less than 0.01 . There is a significant correlation between all the independent variables as listed in Table 4.

Out of 15 correlations, all the $r$-values presented in Table 4 are less than 0.9. Hair et al. (1998) suggested that to ensure non-existence of multi-collinearity, the correlation value should not exceed 0.90 . As shown in Table 4, the highest value of coefficient is 0.851 (process management with people management) which is smaller than 0.90 . Hence, no multicollinearity was found in this present study.

Table 4. Correlation analysis: relationship between independent variables

\begin{tabular}{|c|c|c|c|c|c|c|}
\hline & LD & SP & $\mathrm{CF}$ & HR & $\mathrm{PM}$ & IA \\
\hline LD & 1.000 & & & & & \\
\hline SP & $0.747 * *$ & 1.000 & & & & \\
\hline $\mathrm{CF}$ & $0.636 * *$ & $0.700 * *$ & 1.000 & & & \\
\hline HR & $0.696^{* *}$ & $0.815^{* *}$ & $0.778 * *$ & 1.000 & & \\
\hline PM & $0.669 * *$ & $0.776^{* *}$ & $0.823 * *$ & $0.851 * *$ & 1.000 & \\
\hline IA & $0.601 * *$ & $0.745^{* *}$ & $0.754 * *$ & $0.745^{* *}$ & $0.735 * *$ & 1.000 \\
\hline
\end{tabular}

Note: ${ }^{* *} p<0.01 ; \mathrm{N}=206 ; \mathrm{LD}=$ leadership; $\mathrm{SP}=$ strategic planning; $\mathrm{CF}=$ customer focus; $\mathrm{HR}=$ people management; $\mathrm{PM}=$ process management; IA = information analysis

\subsection{Multiple regression analysis}

To examine the association between TQM dimensions and innovation performance, we have chosen to use multiple linear regression analysis. According to Hair et al. (1998), it is a practical statistical tool that examines the linkages between a set of independent variable with one dependent variable.

In this study, a six-predictor multiple linear regression model was proposed. The sixpredictor variables are leadership $\left(X_{1}\right)$, strategic planning $\left(X_{2}\right)$, customer focus $\left(X_{3}\right)$, process management $\left(X_{4}\right)$, information analysis $\left(X_{5}\right)$, and people management $\left(X_{6}\right)$. The equation of the proposed multiple linear regression model is illustrated as follows:

$$
Y(P 1)=b_{0}+b_{1}\left(X_{1}\right)+b_{2}\left(X_{2}\right)+b_{3}\left(X_{3}\right)+b_{4}\left(X_{4}\right)+b_{5}\left(X_{5}\right)+b_{6}\left(X_{6}\right)+e,
$$

where: $Y(P 1)=$ Dependent variable (innovation performance), $b_{0}=$ Constant, $e=$ Error In relation to the sample size, the estimated parameter ratio of $15: 1$ to $20: 1$ is sufficient to achieve a meaningful estimation of sample size (Hair et al. 1998). In this study, the sample size to the estimated parameter ratio is 34.33:1. According to Hair et al. (1998), it can thus be assumed that sample size in this study is sufficient and adequate. 
Based on this method, the six main independent variables (TQM practices) and dependent variable (innovation performance) were entered together. Table 5 shows the detail of the regression output. As stated by Hair et al. (1998), tolerance indicator needs to be greater than 0.1 and variation inflation factors (VIF) more than 10 to avoid the occurrence of multicollinearity. The VIF and tolerance value presented in Table 5 shows that there is no multicollinearity problem as the tolerance values of more than 0.1 and the VIF values ranged from 2.445 to 5.003, which are less than 10 (Hair et al. 1998).

Table 5. Regression analysis of TQM practices on innovation performance

\begin{tabular}{lcccccc}
\hline & \multicolumn{2}{c}{$\begin{array}{c}\text { Unstandardized } \\
\text { Coefficients }\end{array}$} & \multicolumn{2}{c}{$\begin{array}{c}\text { Standardized } \\
\text { Coefficients }\end{array}$} & \multicolumn{2}{c}{$\begin{array}{c}\text { Collineraity } \\
\text { Statistics }\end{array}$} \\
\hline B & S. E. & $\beta$ & $\mathrm{p}$ & Tolerance & VIF \\
\hline Leadership & 0.341 & 0.108 & & 0.002 & & \\
\hline Strategic Planning & 0.076 & 0.041 & 0.080 & 0.062 & 0.409 & 2.445 \\
\hline Customer Focus & 0.131 & 0.053 & 0.138 & $0.014^{*}$ & 0.239 & 4.187 \\
\hline Information Analysis & 0.100 & 0.047 & 0.113 & $0.035^{*}$ & 0.264 & 3.792 \\
\hline Process Management & 0.676 & 0.057 & 0.722 & $0.000^{* *}$ & 0.200 & 5.003 \\
\hline People Management & 0.187 & 0.060 & 0.190 & $0.002^{* *}$ & 0.201 & 4.970 \\
\hline$R$ & 0.923 & & & & & \\
\hline$R^{2}$ & 0.851 & & & & & \\
\hline F-statistic & 190.096 & & & & & \\
\hline
\end{tabular}

Note: ${ }^{*} p<0.05 ; * * p<0.01$

From Table 5, it can be observed that the coefficient of determination $\left(R^{2}\right)$ is 0.851 , representing that $85.1 \%$ of innovation performance can be explained by the six independent variables (TQM practices). The proposed model is adequate as the F-statistic = $190.096(p$-value $=0.000)$ is significant at the $1 \%$ level $(p<0.01)$. This indicates that the overall model is reasonable fit and there is a statistically significant relationship between TQM practices and innovation performance. The individual model variables reveal that process management, $(\beta=0.722, p<0.01)$, strategic planning $(\beta=0.138$, $p<0.05)$, customer focus $(\beta=0.113, p<0.05)$, and people management $(\beta=0.190$, $p<0.01)$ are found to have a significant and positive relationship with innovation performance. Therefore, the hypotheses H2, H3, H5 and H6 are supported. Meanwhile, leadership $(\beta=0.080, p>0.05)$ and information analysis $(\beta=-0.015, p>0.05)$ has no significant association with innovation performance. However, these practices have bestowed long-term, infrastructural benefits necessary for the continued development over time, but with an indirect association towards innovation performance. Hence, H1 and $\mathrm{H} 4$ are not supported. 


\section{Discussion}

The results of the multiple regression analysis imply that TQM has a significant and positive relationship with innovation performance. Our findings show only four dimensions of TQM, (i.e. process management, strategic planning, people management and customer focus) have to a certain degree, a positive impact on innovation performance of companies surveyed in Malaysia. Our findings also show that leadership and information analysis has an insignificant relationship with innovation performance. This research supports the findings of Singh and Smith (2004), whereby their result obtained could not confirm that all TQM factors have an impact on innovation.

\subsection{Leadership}

The result reveals that leadership is found to be insignificant to enhance the level of innovation performance. This result implies that leadership does not play a major role in innovation from the survey in the Malaysia context. This is contrary to the findings from the literature review, for example; Hoang et al. (2006) in which they concluded that leadership portrays a positive impact on Vietnamese firms' innovation performance in terms of the levels of newness by providing the reason that a supportive management ensures the success of TQM implementation. The findings of this study indicate that the management has yet to provide sufficient leadership in promoting the importance of innovation. This stresses on the need of top management commitment to TQM implementation in order to promote innovation performance within the manufacturing context. As senior management has the power to allocate resources within the organization, it is important for the top management to communicate with the employees and cultivate the innovation culture in the Malaysian manufacturing sector. For example, the top management of the manufacturing organizations in Malaysia shall seek global R\&D partnership and innovation collaboration as a way to develop their core competencies and nurture the innovative culture among the employees.

\subsection{Strategic planning}

The study found that strategic planning shows significant relationship with innovation performance. This implies that the formulation and execution of strategic planning in the manufacturing organizations in Malaysia could improve innovation performance. This result is supported with the findings of Zhang (2000) in which he concluded that vision and statement (i.e. part of the process of strategic planning) have positive relationship with innovation performance. Strategic planning deals with vision and mission mapping as well as cultivation of organizational culture. From the TQM perspective, "quality vision statement" could be used to communicate quality policy. An effective quality vision statement usually entails with clauses that can inspire employees to high levels of performance, and further, to fostering their commitment to TQM (Zhang 2000). Consequently, innovation performance could be enhanced through superior quality services provided by dedicated employees who are guided by a shared vision. Therefore, a good strategic quality planning should be charted by leaders of the organizations to achieve organizational goals that support quality management which in return, will lead to focused innovation performance. 


\subsection{Customer focus}

From this research, customer focus is reported to have a significant positive relationship with innovation performance within the Malaysian manufacturing sector. Our research findings are in line with the findings of Hoang et al. (2006), in which their research confirms that by focusing on the customers' existing and future expectations, firms will improve on their products and services through innovation to achieve greater customer satisfaction. Furthermore, this result is consistent with Lorente et al. (1999)'s argument, in which they posited that as current and future customers' needs are being identified, business innovation will be inspired. However, some researchers found no positive relationship between customer focus and the firm's innovation performance. It is said that being customer centered is not related with product newness (Atuahene-Gima 1996 as cited by Hoang et al. 2006). Furthermore, Prajogo and Sohal (2003) argued that by attending to the direct customers' wants and needs, the company will be confined to satisfying the existing customers' standard requirements alone, creating hindrance towards being innovative. This was also confirmed by Slater and Narver (1998). Prajogo and Sohal (2001) proposed that being customer focused prevents companies from being broad-minded, restraining the firm's ability to innovate, thus preventing firms from becoming industry leaders.

\subsection{Information analysis}

The dimension of information analysis is found to be insignificant to innovation performance. This result is consistent with the findings of Hoang et al. (2006), which confirms the earlier findings of Gustafson and Hundt (1995) and McAdam et al. (1998). Information analysis is the process of analyzing information and searching for ways to reduce differences that original thinking and innovation have been formed and hence a negative relationship exists between information analysis and innovation performance. In this respect, manufacturing organizations in Malaysia have set production efficiency as the main purpose when using information analysis as a control and confirm to the standard rather than using it as a tool for innovation.

\subsection{People management}

The statistical result obtained from this study reveals that people management is found to be positively associated with the levels of innovation performance of a firm. This result is consistent with the comments given by Lorente et al. (1999) in that welltrained employees are more open to accept changes in new systems and operations. This is because through the various training programs provided, the employees' skills are expected to improve and new knowledge is to be acquired. From the discussion, with improved performance, employees should also be duly rewarded especially if they are able to innovate in order to motivate them further.

Training is essential as it changes the attitudes and perspective of employees towards any organizational changes. With a supportive organizational atmosphere, this helps to create a sense of empowerment among employees. According to Lorente et al. (1999), empowered employees are more inclined to continuous improvement when they are involved in 
the change process. This could be due to the fact that employees' morale and confidence are elevated when training is provided, employees are more receptive to change, which will determine the success of organizational innovation (Prajogo, Sohal 2001).

\subsection{Process management}

The results in this study demonstrate favorably that process management is found to be significant and contribute to the enhancement of innovation within the Malaysian manufacturing sector. This result provides supporting evidence from the findings of Prajogo and Sohal (2003) in which there was a link between process management and innovation was being studied for a large manufacturing firm in Australia. Analysis of the research findings suggests that as the company adopts stricter quality systems and standard into its production process itself (due to pressure from its customer and the industry itself to achieve high quality performance), the company started to apply new technologies into its manufacturing processes. As more investment was being made to purchase the advanced equipment for automation, this enables the company to achieve a higher level of process capability. As a result, the manufacturing firm is required to come up with a new set of products, coupled with built in features, commensurate with the level of automation. This proves that processes can dictate the design features of a product; hence a positive relationship exists between product innovation and process innovation. This is further confirmed by Lorente et al. (1999)'s findings where they concluded that companies that adopt TQM practices are more receptive to accept management innovation.

\section{Research implications}

In this study, a current research in the area of TQM has been revisited and implications in both theoretical and managerial perspectives have been found. These implications are discussed in the next section.

\subsection{Theoretical implications}

From the theoretical perspectives, this study provides a better perception on the six TQM dimensions and their importance towards increasing innovation performance within the manufacturing context. It is believed that this study can fill in the current knowledge gap in connection to the linkages between the practices of TQM with innovation performance. The theoretical framework that was developed emphasized on those TQM elements that are particularly essential in determining a high level of innovation performance among the manufacturing firms. Moreover, there are very limited empirical studies that examine the multidimensionality of TQM principles which smooth the progress of the level of innovation performance within a manufacturing setting, particularly in a developing country such as Malaysia. With the present findings, it is believed to assist the manufacturing firms in increasing their levels of innovation activities. Apart from that, with its relatively new concept, the empirical research may also capture the attention of other researchers in seeking out to find the right circumstances that are most conducive to the establishment of innovation performance, particularly in the domain of TQM. 


\subsection{Managerial implications}

Practically, this study reveals that customer focus, strategic planning, people management and process management are positively associated with innovation performance. Therefore, in Malaysia's manufacturing context, to promote innovation, the management might want to look into these four TQM practices which are seen to be vital links.

Firstly, it is suggested that with the positive relationship between customer focus and innovation performance, organizations ought to set up clear customer focus strategy such as with proper customer relationship management system, customer feedback system and customer care system. Next, strategic planning encompasses setting the direction of the company; the respondents are of the opinion that strategic planning would have a positive relationship with innovation performance; therefore it is suggested the organizations should establish the strategic planning and setting the direction of the organization clearly for innovation performance. Thirdly, people management is seen to have a positive relationship with innovation performance. Practices of people management such as training and development, teamwork, appropriate delegation are some of the key steps from the people management. Managers are advised to weight into for better innovation performance. Last but not least, process management is also seen to be related to the innovation performance. This finding might be attributed to the scenario where Malaysian manufacturing sectors are seen to be a strong contender in terms of third party contract manufacturing roles for the multi national firms instead of own brand building and own product development. Therefore, to be competitive in the business environment, good process management is seen to be related to innovation performance.

Whereas for the investigation on two other TQM practices, leadership and information analysis; are not perceived to be of strong relationship with the innovation performance. Perhaps, the management needs to adopt a more liberal approach in promoting innovation performance since the respondents is of the opinion that leadership does not have a strong relationship with it. At the same time, the respondents also see lesser relationship between information analysis and innovation performance. This might be the perception of the role of information analysis are viewed as the supporting function in the manufacturing context which emphasized more on production efficiency in Malaysia (i.e. mainly contract manufacturing or off-shoot of MNCs) instead of playing the leading role in an organization.

\section{Research limitations and future research}

In order to determine possible future research opportunities, several limitations of this study should be noted. Firstly, the time sequence of the relationships between the variables could not be determined since cross-sectional data were used. Thus, the findings of this study should not be taken as proof of the causal relationships. It is recommended that longitudinal research designs should be applied to provide the evidence of causality that is not obtainable through the designs of cross-sectional studies.

Secondly, this study was confined only to the manufacturing industry in Malaysia. It is suggested that future research should cover both manufacturing and service industries. 
In essence, both industries are different: service industry depends heavily on people to produce services while manufacturing industry focuses on producing physical products. Thus, both industries may need different management practices and quality improvement programs. A comparison could be made in terms of the relationships between the types of organization and TQM practices among these two industries. It is also essential to also take note that the background of the companies under investigation is also not included in this present study. Hence, it would be beneficial if future research can conduct a detail breakdown of the companies' background as well as their life cycle stages, so that a further analysis and discussion can be conducted.

Thirdly, despite its cost-effectiveness and sample coverage (i.e. larger samples are collected compared with the interviews method), questionnaire survey may suffer from response bias and lack of respondent awareness. It is suggested that further analysis may be needed to explore and expand the research through field observations and interviews of managers from the sample. Finally, since the constructs of customer focus, process management, strategic planning and people management are reported to have significant positive relationship with innovation performance, future research might explore the robustness of these associations. For instance, the researchers might examine to what extent these four significant dimensions enhance innovation performance. Likewise, the exploration of the robustness of these associations would have made the results more reliable.

Furthermore, apart from the six TQM practices, other factors that can affect innovation performance were not taken into consideration. One such factor will be motivation from regulatory requirements. Regulations from environmental groups as well as the government to control the activities of the firms can indeed motivate a company to become more creative, generating newer ideas and developing more eco friendly products that lessen environmental pollution. As such, it can be expected that such factor can have a strong linkage with innovation performance.

Lastly, although this study has appropriately employed multiple regression analysis which analyzes the relationship between a single dependent variable (i.e. innovation performance) and several independent variables (i.e. TQM practices), future studies could use other multivariate technique such as structural equation modeling (SEM) which has the ability to incorporate unobserved constructs in the relationships and account for measurement errors in the analysis.

\section{Conclusion}

From the study presented, we have identified four TQM constructs that are having significant relationships with innovation performance namely strategic planning, customer focus, people management and process management. We have further identified two constructs that are found not to have significant relationship with innovation performance, i.e. leadership and, information analysis. Both of these findings are in the context of Malaysian manufacturing companies. Innovation performance and to be innovative no doubt are critical to the ability to be competitive in the market place. Malaysian 
companies are not known to be innovative as its economy is still at the developing stage. Furthermore, the uniqueness in the Malaysian development model thus far has been relying on low value foreign labour input to a great extent. With the reliance on low value foreign labour input, it is believed by many quarters that this development strategy has stifled the innovation performance and process of up the value chain development among the industrialists in Malaysia. Therefore, it was not really a surprise that leadership was seen to be lacking in innovation performance from this study.

\section{Acknowledgement}

The authors would like to acknowledge the research contribution of Ms Ang Yueh Sin who particularly helped in the data collection.

Pei-Lee Teh is currently attached to Monash University, Malaysia. She can be contacted at teh.pei.lee@monash.edu.

Alain Yee Loong Chong is currently attached to Nottingham University Business School China, University of Nottingham (Ningbo Campus).

\section{References}

Abrunhosa, A.; Sa, P. M. E. 2008. Are TQM principles supporting innovation in the Portuguese footwear industry, Technovation 28(4): 208-221.

http://dx.doi.org/10.1016/j.technovation.2007.08.001

Adam, E. E. Jr.; Corbett, L. M.; Flores, B. E.; Harrison, N. J.; Lee, T. S.; Rho, B. H.; Ribera, J.; Samson, D.; Westbrook, R. 1997. An international study of quality improvement approach and firm performance, International Journal of Operations and Production Management 17(9): 842873. http://dx.doi.org/10.1108/01443579710171190

Ahire, S. L.; Golhar, D. Y.; Waller, M. A. 1996. Development and validation of TQM implementation constructs, Decision Sciences 27(1): 23-56.

http://dx.doi.org/10.1111/j.1540-5915.1996.tb00842.x

Ahmed, P. K. 1998. Culture and climate for innovation, European Journal of Innovation Management 1(1): 30-43. http://dx.doi.org/10.1108/14601069810199131

Anderson, J. C.; Rungtusanatham, M.; Schroeder, R. G.; Devaraj, S. 1995. A path analytic model of a theory of quality management underlying the Deming management method: preliminary empirical findings, Decision Sciences 26(5): 637-658.

http://dx.doi.org/10.1111/j.1540-5915.1995.tb01444.x

Atuahene-Gima, K. 1996. Market orientation and innovation, Journal of Business Research 35(2): 93-103. http://dx.doi.org/10.1016/0148-2963(95)00051-8

Benner, M. J.; Tushman, M. 2003. Exploitation, exploration, and process management: the productivity dilemma revisited, Academy of Management Review 28(2): 238-256.

Bolwijn, P. T.; Kumpe, T. 1990. Manufacturing in the 1990s - productivity, flexibility and innovation, Long Range Planning 23(4): 44-57. http://dx.doi.org/10.1016/0024-6301(90)90151-S

Bowen, D. E.; Lawler III, E. E. 1992. Total quality-oriented human resources management, Organizational Dynamics 20(4): 29-41. http://dx.doi.org/10.1016/0090-2616(92)90073-V

Calantone, R. J.; Vickery, S. K.; Droge, C. 1995. Business performance and strategic new product development activities: an empirical investigation, Journal of Product Innovation Management 12: 214-223. http://dx.doi.org/10.1111/1540-5885.1230214 
Carayannis, E. G.; Alexander, J.; Ioannidis, A. 2000. Leveraging knowledge, learning, and innovation in forming strategic government-university-industry (GUI) R\&D partnerships in the US, Germany, and France, Technovation 20: 477-488.

http://dx.doi.org/10.1016/S0166-4972(99)00162-5

Chau, P. Y. K.; Hu, P. J. H. 2001. Information technology acceptance by individual professional: a model comparison approach, Decision Sciences 32(4): 699-719.

http://dx.doi.org/10.1111/j.1540-5915.2001.tb00978.x

Choi, T. Y.; Eboch, K. 1998. The TQM paradox: relations among TQM practices, plant performance, and innovation performance, Journal of Operations Management 17(1): 59-75. http://dx.doi.org/10.1016/S0272-6963(98)00031-X

Claver, E.; Llopis, J.; Garcia, D.; Molina, H. 1998. Organizational culture for innovation and new technological behavior, The Journal of High Technology Management Research 9: 55-68. http://dx.doi.org/10.1016/1047-8310(88)90005-3

Cohen, W.; Levinthal, D. 1990. Absorptive capacity: a new perspective on learning and innovation, Administrative Science Quarterly 35: 128-152. http://dx.doi.org/10.2307/2393553

Cooper, J. R. 1998. A multidimensional approach to the adoption of innovation, Management Decision 38(8): 493-502. http://dx.doi.org/10.1108/00251749810232565

Cooper, R. G. 1993. Winning at New Products - Accelerating the Process from Idea to Lauch. Reading, MA, Addison-Wesley Publishing Company.

Cooper, R. G. 2003. Profitable product innovation: the critical success factors, in Shavinina, L. V. (Ed.). The International Handbook on Innovation. Elsevier Science, Barking, 139-157.

Cottam, A.; Ensor, J.; Band, C. 2001. A benchmark study of strategy commitment to innovation, European Journal of Innovation Management 4(2): 88-94.

http://dx.doi.org/10.1108/14601060110390594

Damanpour, F. 1996. Organisational complexity and innovation: developing and testing multiple contingency models, Management Science 42(5): 693-716.

http://dx.doi.org/10.1287/mnsc.42.5.693

Dean, Jr. J. W.; Bowen, D. E. 1994. Management theory and total quality: improving research and practice through theory development, The Academy of Management Review 19(3): 392-418.

Department of Statistics Malaysia. 2010. Population [cited 11 June 2010]. Available from Internet: http://www.statistics.gov.my/portal/index.php?option=com_content\&view=article $\&$ id $=54 \% 3$ Apopulation-updated-31072009\&catid=35\%3Akey-statistics\&Itemid=53\&lang=en

Drew, S. A. W. 2006. Building technology foresight: using scenarios to embrace innovation, European Journal of Innovation Management 9(3): 241-257.

http://dx.doi.org/10.1108/14601060610678121

Easton, G. S.; Jarrell, S. L. 1998. The effects of total quality management on corporate performance: an empirical investigation, Journal of Business 71(2): 253-307.

http://dx.doi.org/10.1086/209744

Economist Intelligence Unit. 2009. Making up for lost time, Business China 35(10): 1-12.

Economist Intelligence Unit. 2010. Country Report: Malaysia March 2010. United Kingdom: The Economist Intelligence Unit.

Ehigie, B. O.; McAndrew, E. B. 2005. Innovation, diffusion and adoption of total quality management (TQM), Management Decision 43(6): 925-940. http://dx.doi.org/10.1108/00251740510603646

Evans, J. R.; Lindsay, W. M. 1999. The Management and Control of Quality, South Western College Publishing. Cincinnati, $\mathrm{OH}$.

Fang, Z. 2005. Exploring the synergy between entrepreneurship and innovation, International Journal of Entrepreneurial Behavior and Research 11(1): 25-41.

http://dx.doi.org/10.1108/13552550510580825 
Federation of Malaysian Manufacturers (FMM) Directory. 2007. Malaysian Industries. $38^{\text {th }}$ ed. Kuala Lumpur. ISSN 0126-9801.

Feng, J.; Prajogo, D. I.; Tan, K. C.; Sohal, A. S. 2006. The impact of TQM practices on performance: a comparative study between Australian and Singaporean organizations, European Journal of Innovation Management 9(3): 269-278. http://dx.doi.org/10.1108/14601060610678149

Flynn, B. B.; Schroeder, R. G.; Sakakibara, S. 1994. A framework for quality management research and an associated measurement instrument, Journal of Operations Management 11: 339-366. http://dx.doi.org/10.1016/S0272-6963(97)90004-8

Fuentes-Fuentes, M. M.; Albacete-Saez, C. A.; Llorens-Montes, F. J. 2004. The impact of environmental characteristics on TQM principles and organizational performance, Omega - International Journal of Management Science 32: 425-442.

Garcia-Morales, V. J.; Matias-Reche, F.; Hurtado-Torres, N. 2008. Influence of transformational leadership on organizational innovation and performance depending on the level of organizational learning in the pharmaceutical sector, Journal of Organizational Change Management 21(2): 188-212. http://dx.doi.org/10.1108/09534810810856435

Garvin, D. A. 1983. Quality on the line, Harvard Business Review 61: 64-75.

Geffen, C. A.; Rothenberg, S. 2000. Suppliers and environmental innovation: the automotive paint process, International Journal of Operations and Production Management 20(2): 166-186. http://dx.doi.org/10.1108/01443570010304242

Grant, R. M. 1996. Toward a knowledge-based theory of the firm, Strategic Management Journal 17: 109-122.

Gray, D. H. 1986. Uses and misuses of strategic planning, Harvard Business Review 64(1): 89-97.

Griffin, A. 1997. PDMA research on new product development practices: updating trends and benchmarking best practices, Journal of Product Innovation Management 16: 429-458.

http://dx.doi.org/10.1016/S0737-6782(97)00061-1

Guan, J. C.; Mok, C. K.; Yam, R. C. M.; Chin, K. S.; Pun, K. F. 2006. Technology transfer and innovation performance: evidence from Chinese firms, Technological Forecasting and Social Change 73: 666-678. http://dx.doi.org/10.1016/j.techfore.2005.05.009

Gustafson, D. H.; Hundt, A. S. 1995. Findings of innovation research applied to quality management principles for health care, Health Care Management Review 20(2): 16-33.

Hair, J. F.; Anderson, R. E.; Tatham, R. L.; Blank, W. C. 1998. Multivariate Data Analysis. Prentice Hall, Englewood Cliffs, NJ.

Han, J. K.; Kim, N.; Srivasta, R. K. 1998. Market orientation and organisational performance: is innovation a missing link?, Journal of Marketing 62: 30-45.

Hart, C.; Schlesinger, L. 1991. Total quality management and the human resource professional: applying the Baldrige framework to human resources, Human Resource Management 30(4): 433-454. http://dx.doi.org/10.1002/hrm.3930300402

Hartman, E. A.; Tower, C. B.; Sebora, T. C. 1994. Information sources and their relationship to organizational innovation in small business, Journal of Small Business Management 32(1): 36-47.

Hoang, D. H.; Igel, B.; Laosirihongthong, T. 2006. The impact of total quality management on innovation: findings from a developing country, International Journal of Quality and Reliability Management 23(9): 1092-1117. http://dx.doi.org/10.1108/02656710610704230

Jassawalla, A. R.; Sashittal, H. C. 2002. Cultures that support product innovation processes, Academy of Management Executive 16: 42-54. http://dx.doi.org/10.5465/AME.2002.8540307 
Jong, J. P. J.; Hartog, D. N. 2007. How leaders influence employees' innovative behavior, European Journal of Innovation Management 10(1): 41-64. http://dx.doi.org/10.1108/14601060710720546

Jung, J. Y.; Wang, Y. J. 2006. Relationship between total quality management (TQM) and continuous improvement of international project management (CIIPM), Technovation 26: 716-722. http://dx.doi.org/10.1016/j.technovation.2006.01.003

Kanji, G. K. 1998. An innovative approach to make ISO 9000 standards more effective, Total Quality Management 9(1): 67-78. http://dx.doi.org/10.1080/0954412989270

Kanji, G. K. 2008. Leadership is prime: how do you measure leadership excellence, Total Quality Management 19(4): 417-427. http://dx.doi.org/10.1080/14783360802002834

Kanter, R. M. 1983. The Change Masters. New York, NY: Simon \& Schuster.

Karnitis, E. 2006. A knowledge-based human-centred growth model for Latvia, Journal of Business Economics and Management 7(3): 95-101.

Kirner, E.; Kinkel, S.; Jaeger, A. 2009. Innovation paths and the innovation performance of low-technology firms - an empirical analysis of German industry, Research Policy 38: 447-458. http://dx.doi.org/10.1016/j.respol.2008.10.011

Krogh, G. V.; Nonaka, I.; Aben, M. 2001. Making the most of your company's knowledge: a strategic framework, Long Range Planning 34: 421-439.

http://dx.doi.org/10.1016/S0024-6301(01)00059-0

Labor Force Survey. 2010. Employment [cited 11 June 2010]. Available from Internet: http:// www.statistics.gov.my/portal/index.php?option=com_content\&view=article\&id $=421 \% 3 \mathrm{Aemploy}$ ment-updated31052010-\&catid=35\%3Akey-statistics\&Itemid $=53 \&$ lang $=$ en

Lemos, A. D.; Porto, A. C. 1998. Technological forecasting techniques and competitive intelligence: tools for improving the innovation process, Industrial Management and Data Systems 98(7): 330-337. http://dx.doi.org/10.1108/02635579810227698

Liedtka, J. 2000. Strategic planning as a contributor to strategic change: a generative model, European Management Journal 18(2): 195-206. http://dx.doi.org/10.1016/S0263-2373(99)00091-2

Lin, H. F.; Lee, G. G. 2004. Perceptions of senior managers toward knowledge-sharing behavior, Management Decision 42(1): 108-125. http://dx.doi.org/10.1108/00251740410510181

Lisinski, M.; Saruckij, M. 2006. Principles of the application of strategic planning methods, Journal of Business Economics and Management 7(2): 37-43.

Loof, H.; Heshmati, A. 2002. Knowledge capital and performance heterogeneity: a firm-level innovation study, International Production Economics 76: 61-85.

Lorange, P. 1980. Corporate Planning: an Executive Viewpoint. Prentice-Hall, Englewood Cliffs, NJ.

Lorente, A. R. M.; Dewhurst, F.; Dale, B. G. 1999. TQM and business innovation, European Journal of Innovation Management 2(1): 12-19. http://dx.doi.org/10.1108/14601069910248847

Maidique, M. A.; Zirger, B. J. 1984. A study of success and failure in product innovation: the case of the US electronics industry, IEEE Transactions in Engineering Management 31: 192-203.

Malaysian Industrial Development Authority. 2009. Malaysia moves up three places in innovation index [cited 8 March 2010]. Available from Internet: http://www.mida.gov.my/en_v2/index. php?mact=News,cntnt01, detail,0\&cntnt01 articleid=333\&cntnt01 returnid=109

Mankin, E. 2007. Measuring innovation performance, Research Technology Management 50(6): 5-7.

Martensen, A. 1998. Leadership for product development: a business excellence approach, Total Quality Management 9: 172-176. http://dx.doi.org/10.1080/0954412988839

Martensen, A.; Dahlgaard, J. J. 1999. Strategy and planning for innovation management - a business excellence approach, International Journal of Quality and Reliability Management 16(8): 734-755. http://dx.doi.org/10.1108/02656719910283344 
Martin, Jr. C. R.; Horne, D. A. 1993. Service innovation: successful versus unsuccessful firms, International Journal of Service Industry Management 4(1): 49-65.

McAdam, R.; Armstrong, G.; Kelly, B. 1998. Investigation of the relationship between total quality and innovation: a research study involving small organizations, European Journal of Innovation Management 1(3): 139-147. http://dx.doi.org/10.1108/14601069810230216

Mele, C.; Colurcio, M. 2006. The evolving path of TQM: towards business excellence and stakeholder value, International Journal of Quality and Reliability Management 23(5): 464-489. http://dx.doi.org/10.1108/02656710610664569

Ministry of Home Affairs. 2010. Number of foreign workers in Malaysia by sector, 19992008 [cited 11 June 2010]. Available from Internet: http://www.statistics.gov.my/portal/index. php?lang=en

Mintzberg, H. 1994. The fall and rise of strategic planning, Harvard Business Review 72(1): 107-114.

Miranda, A. 2003. Total quality management and inequality: the triple helix in global historical perspective, Science, Technology and Human Values 28(1): 34-51.

http://dx.doi.org/10.1177/0162243902238494

Molina, L. M.; Llorens-Montes, J.; Ruiz-Moreno, A. 2007. Relationship between quality management practices and knowledge transfer, Journal of Operations Management 25: 682-701.

http://dx.doi.org/10.1016/j.jom.2006.04.007

Montes, F. J. L.; Moreno, A. R.; Molina, L. M. 2003. An analysis of the relationship between quality and perceived innovation: the case of financial firms, Industrial Management and Data Systems 103(8): 579-590. http://dx.doi.org/10.1108/02635570310497620

Narver, J. C.; Slater, S. F. 1990. The effect of a market orientation on business profitability, Journal of Marketing 54(4): 20-35. http://dx.doi.org/10.2307/1251757

Nunnally, J. C.; Bernstein, I. H. 1994. Psychometric Theory. $3^{\text {rd }}$ ed. New York: McGraw-Hill Inc.

Oldham, G. R.; Cummings, A. 1996. Employee creativity: personal and contextual factors at work, Academy of Management Journal 39: 607-634. http://dx.doi.org/10.2307/256657

Ooi, K. B.; Arumugam, V.; Teh, P. L.; Chong, A. Y. L. 2008. TQM practices and its association with production workers, Industrial Management and Data Systems 108(7): 909-927.

http://dx.doi.org/10.1108/02635570810897991

Ooi, K. B.; Safa, M. S.; Arumugam, V. 2006. TQM practices and affective commitment: a case of Malaysian semiconductor packaging organizations, International Journal of Management and Entrepreneurship 2(1): 37-55.

Pinho, J. S. 2008. TQM and performance in small medium enterprises, International Journal Management 25(3): 256-275.

Powell, T. C. 1995. Total quality management as competitive advantage: a review and empirical study, Strategic Management Journal 16(1): 15-27. http://dx.doi.org/10.1002/smj.4250160105

Prajogo, D. I.; Ahmed, P. K. 2006. Relationship between innovation stimulus, innovation capacity, and innovation performance, $R \& D$ Management 36(5): 499-515.

http://dx.doi.org/10.1111/j.1467-9310.2006.00450.x

Prajogo, D. I.; Hong, S. W. 2008. The effect of TQM on performance in R\&D environements: a perspective from South Korean firms, Technovation 38: 855-863.

http://dx.doi.org/10.1016/j.technovation.2008.06.001

Prajogo, D. I.; Sohal, A. S. 2001. TQM and innovation: a literature review and research framework, Technovation 21: 539-558. http://dx.doi.org/10.1016/S0166-4972(00)00070-5

Prajogo, D. I.; Sohal, A. S. 2003. The relationship between TQM practices, quality performance, and innovation performance: an empirical examination, International Journal of Quality and Reliability Management 20(8): 901-918. http://dx.doi.org/10.1108/02656710310493625 
Prajogo, D. I.; Sohal, A. S. 2004a. Transitioning from total quality management to total innovation management: an Australian case, International Journal of Quality and Reliability Management 21(8): 861-875. http://dx.doi.org/10.1108/02656710410551746

Prajogo, D. I.; Sohal, A. S. 2004b. The multidimensionality of TQM practices in determining quality and innovation performance - an empirical examination, Technovation 24: 443-453. http://dx.doi.org/10.1016/S0166-4972(02)00122-0

Prajogo, D. I.; Sohal, A. S. 2006. The integration of TQM and technology/R\&D management in determining quality and innovation performance, Omega - The International Journal of Management Science 34: 296-312.

Prajogo, D. I.; Laosirihongthong, T.; Sohal, A.; Boon-Itt, S. 2007. Manufacturing strategies and innovation performance in newly industrialized countries, Industrial Management \& Data Systems 107(1): 52-68. http://dx.doi.org/10.1108/02635570710719052

Puffer, S. M.; McCarthy, D. J. 1996. A framework for leadership in a TQM context, Journal of Quality Management 1(1): 109-130. http://dx.doi.org/10.1016/S1084-8568(96)90008-5

Raghunathan, T. S.; Rao, S. S.; Solis, L. E. 1997. A comparative study of quality practices: USA, China and India, Industrial Management \& Data Systems 97(5): 192-200.

http://dx.doi.org/10.1108/02635579710367270

Rahman, S. 2002. Leadership and HR focus in TQM research in Australia: an assessment and agenda, Benchmarking: An International Journal 9(5): 485-505.

Ravichandran, T.; Rai, A. 2000. Quality management in systems development: an organizational system perspective, MIS Quarterly 24(3): 381-415. http://dx.doi.org/10.2307/3250967

Rungtusanatham, M.; Forza, C.; Filippini, R.; Anderson, J. C. 1998. A replication study of a theory of quality management underlying the Deming management method: insights from an Italian context, Journal of Operations Management 17: 77-95.

http://dx.doi.org/10.1016/S0272-6963(98)00032-1

Samson, D.; Terziovski, M. 1999. The relationship between total quality management practices and operational performance, Journal of Operations Management 17: 393-409.

http://dx.doi.org/10.1016/S0272-6963(98)00046-1

Saraph, J. V.; Benson, P. G.; Schroeder, R. G. 1989. An instrument for measuring critical factors of quality management, Decision Sciences 20(4): 810-829.

http://dx.doi.org/10.1111/j.1540-5915.1989.tb01421.x

Savolainen, T. 2000. Leadership strategies for gaining business excellence through total quality management: a Finnish case study, Total Quality Management 11(2): 211-226.

http://dx.doi.org/10.1080/0954412006955

Schonberger, R. J. 1992. Total quality management cuts a broad swath-through manufacturing and beyond, Organizational Dynamics 20(4): 16-28. http://dx.doi.org/10.1016/0090-2616(92)90072-U

Scott, S. G.; Bruce, R. A. 1994. Determinants of innovative behavior: a path model of individual innovation in the workplace, Academy of Management Journal 37: 580-607.

http://dx.doi.org/10.2307/256701

Senge, P. M.; Roberts, C.; Ross, R. B.; Smith, B. J.; Kleiner, A. 1994. The Fifth Discipline Fieldbook. Doubleday, New York, NY.

Shah Alam, S.; Yasin, N. M. 2010. The antecedents of online brand trust: Malaysian evidence, Journal of Business Economics and Management 11(2): 210-226.

http://dx.doi.org/10.3846/jbem.2010.10

Sila, I. 2007. Examining the effects of contextual factors on TQM and performance through the lens of organizational theories: an empirical study, Journal of Operations Management 25(1): 83-109. http://dx.doi.org/10.1016/j.jom.2006.02.003 
Singh, P. J.; Smith, A. J. R. 2004. Relationship between TQM and innovation: an empirical study, Journal of Manufacturing Technology Management 15(5): 394-401.

http://dx.doi.org/10.1108/17410380410540381

Slater, S. F.; Narver, J. C. 1998. Customer-led and market-led: let's not confuse the two, Strategic Management Journal 19(10): 1001-1006.

http://dx.doi.org/10.1002/(SICI)1097-0266(199810)19:10<1001::AID-SMJ996>3.0.CO;2-4

Solis, L. E.; Raghunathan, T. S.; Rao, S. S. 2000. A regional study of quality management infrastructure practices in USA and Mexico, International Journal of Quality and Reliability Management 17(6): 597-614. http://dx.doi.org/10.1108/02656710010336749

Sun, H.; Cheng, T. K. 2002. Comparing reasons, practices and effects of ISO 9000 certification and TQM implementation in Norwegian SMEs and large firms, International Small Business Journal 20(4): 421-441. http://dx.doi.org/10.1177/0266242602204003

Taylor, W. A.; Wright, G. H. 2003. A longitudinal study of TQM implementation: factors influencing success and failure, Omega - The International Journal of Management Science 31: 97-111.

Tidd, J.; Bessant, J.; Pavitt, K. 1997. Managing innovation: integrating technological, market, and organizational change. John Wiley \& Sons Ltd, Chichester, UK.

Tushman, M.; Nadler, D. 1986. Organizing for innovation, California Management Review 28(3): 74-92. http://dx.doi.org/10.1287/mnsc.32.5.590

Van de Ven, A. H. 1986. Central problems in the management of innovation, Management Science 32(5): 590-607.

Wang, C.; Kafouros, M. I. 2009. What factors determine innovation performance in emerging economies? Evidence from China, International Business Review 18: 606-616.

http://dx.doi.org/10.1016/j.ibusrev.2009.07.009

Westphal, J. D.; Gulati, R.; Shortell, S. M. 1997. Customization or conformity? An institutional and network perspective on the content and consequences of TQM adoption, Administrative Science Quarterly 42(2): 366-394. http://dx.doi.org/10.2307/2393924

Wilson, D. D.; Collier, D. A. 2000. An empirical investigation of the Malcolm Baldrige national quality award causal model, Decision Sciences 31(2): 361-390.

http://dx.doi.org/10.1111/j.1540-5915.2000.tb01627.x

Wind, J.; Mahajan, V. 1997. Issues and opportunities in new product development: an introduction to the special issue, Journal of Marketing Research 34(1): 1-12.

http://dx.doi.org/10.2307/3152060

Woodman, R. W.; Sawyer, J. E.; Griffin, R. W. 1993. Toward a theory of organizational creativity, Academy of Management Review 18: 293-321.

Wright, P. M.; Dunford, B. B.; Snell, S. A. 2001. Human resources and the resource based view of the firm, Journal of Management 27: 701-721. http://dx.doi.org/10.1177/014920630102700607

Zafiropoulos, C.; Vrana, V. 2008. Service quality assessment in a Greek higher education institute, Journal of Business Economics and Management 9(1): 33-45.

http://dx.doi.org/10.3846/1611-1699.2008.9.33-45

Zeng, S. X.; Xie, X. M.; Tam, C. M. 2010. Relationship between cooperation networks and innovation performance of SMEs, Technovation 30: 181-194.

http://dx.doi.org/10.1016/j.technovation.2009.08.003

Zhang, Z. 2000. Developing a model of quality management methods and evaluating their effects on business performance, Total Quality Management 11(1): 129-137.

http://dx.doi.org/10.1080/0954412007071 
Keng-Boon OOI is an Associate Professor for the Faculty of Business and Finance, University Tunku Abdul Rahman, Malaysia. He is also a Singapore Internet Research Centre Associate with the Wee Kim Wee School of Communication and Information, Nanyang Technology University, Singapore. He has published over 60 articles in refereed journals.

Binshan LIN is the BellSouth Corporation Professor at Louisiana State University in Shreveport. He received his Ph.D. from the Louisiana State University. Dr Lin is a nine-time recipient of the Outstanding Faculty Award at LSUS. Professor Lin receives the Computer Educator of the Year by the International Association for Computer Information Systems (IACIS) in 2005, Ben Bauman Award for Excellence in IACIS 2003, Distinguished Service Award at the Southwest Decision Sciences Institute (SWDSI) in 2007, and Outstanding Educator Award at the SWDSI in 2004. He has published over 250 articles in refereed journals.

Pei-Lee TEH is currently a Senior Lecturer with the School of Business, Monash University, Malaysia. She is a member of the Asian Business Strategy research strength. Prior to joining Monash University, she was a Senior Lecturer in Multimedia University, Malaysia. Her teaching and research interests cover Total Quality Management, Technology Management, Management Information Systems, Knowledge Management, Innovation and Learning. She has authored or co-authored several papers published in international journals and conferences.

Alain Yee-Loong CHONG is an assistant professor in the Nottingham University Business School China, University of Nottingham, Ningbo campus. Before that, he was a postdoctoral fellow in the Department of Industrial and Systems Engineering, The Hong Kong Polytechnic University. His research interests include supply chain management, e-business adoption and service science. His papers have been accepted/published in journals such as International Journal of Production Economics, Decision Support Systems, Production Planning and Control and Journal of Computer Information Systems. He is a Member of the Institute of Electrical and Electronics Engineers (IEEE). 